\title{
ENTREPRENEURSHIP IN A CONTEXT OF PENDING RETIREMENT: THE LIVED EXPERIENCE OF OLDER ENTREPRENEURS
}

\section{Introduction}

Despite being a relatively recent construct, retirement has been very successfully sold to working people (Freedman, 2007). The established pattern of winding down or ending fulltime work around the age of 65 (or earlier) to enjoy a life of hobbies and interests is part of the modern life-plan for many people and there is an expectation to 'let go gracefully' accompanying visions of what a 'normal' working life resembles (Kotter, 1985). The normative effects of retirement exert influence long before paid work is left for good; retirement reaches back into working lives in forms such as pension planning or other provision and creates assumptions over what older people want from paid work and for how long. The dispositions concerning working life have consequently been adapted and propagated: with 'old' age comes economic disengagement (Beckhard, 1977). For these reasons the transition to retirement is best considered as a complex process rather than a discrete event (Zissimopoulos and Karoly, 2009). But how do the processes and expectations associated with approaching retirement affect those who are self-employed?

What are the experiences of entrepreneurship in a context of pending retirement?

The prospects for people in the context of pending retirement in starting their own businesses have recently gained fresh attention among those concerned with the situation of older people in the labour market (Kautonen, 2008; Kautonen et al., 2008; Kibler et al., 
[Type here]

2011). In the UK, for example, charity and government policy has considered whether selfemployment could offer a means of overcoming problems such as various forms of discrimination and disadvantage experienced by older people in paid employment (PRIME, 2011) and the problems surrounding pensions (Vickerstaff and Cox, 2005). Insights into the advantages and disadvantages facing these older entrepreneurs have been provided by conceptual and empirical research (Kautonen et al., 2008; Kibler et al., 2011; Mallett and Wapshott, forthcoming; Singh and DeNoble 2003) but there has been limited voice given to the entrepreneurs themselves. In this chapter we are interested in how those engaged in forms of entrepreneurship relate to their pending retirement, in particular how it impacts on their motivations, life-work tensions and personal relationships, and their relationships with their respective ventures.

Without a sense of practitioners' personal accounts of their experiences, the prospects for entrepreneurship addressing problems facing older workers can only be partially understood. Echoing recent debates in the entrepreneurship literature more widely, we suggest that overlooking the everyday accounts of entrepreneurs risks missing the detail of entrepreneurs' lived experience (Morris et al., 2012), hampering our understanding of entrepreneurship more generally (Baron, 2000; Down, 2006). There is a need for in-depth empirical work on the everyday lived experiences of older entrepreneurs (Kautonen, 2008; Kibler et al., 2011; Wainwright et al., 2012).

This chapter contributes to addressing this gap by presenting two longitudinal case studies of entrepreneurs as one, Thomas, sets out to create a venture before he retires and another, Edward, considers closing his business and retiring. Joining Thomas and Edward on their 
contrasting entrepreneurial journeys we reveal and discuss how entrepreneurship in a context of pending retirement can be a messy, complex and highly emotional process in ways that existing research has yet to fully explore. We discuss our findings in terms of how founding and running a business later in life can be subject to complexities and degrees of risk that have a bearing on the lived experience of older entrepreneurs. In concluding, we reflect on how our in-depth qualitative findings contribute to discussions of the 'messiness' of entrepreneurship in the context of pending retirement and identify how they might inform further research in this area.

\section{Entrepreneurship and older entrepreneurs}

As the adult populations of the world's large economies age, extending lifespans amidst significant shortfalls in pension funds (Dini, 2009; Vickerstaff and Cox, 2005), many people are working for longer (Ekerdt, 2010). As the recent trend towards early retirement is therefore reversed (McNair, 2010), a reorientation of attitudes towards older people in work will be required (Wainwright et al., 2012). At present, many older workers are

frequently excluded from work altogether or moved into relatively low-skill jobs that contain little scope for financial and other rewards (Riach, 2007) leaving many older people 'too old to work and too young to die' (Freedman, 2007, p.43). One potential antidote offered to low-skill, low-pay service sector jobs may be for some older workers to create second careers in self-employment (Curran and Blackburn, 2001; Kautonen et al., 2008).

This focus on older entrepreneurs and self-employment in the context of pending retirement is a relatively recent development and it remains an under-researched topic, although the 
motivations and possibilities for older people to establish entrepreneurial ventures have been widely discussed (Weber and Schaper, 2004). Entrepreneurship is a way of extending working lives (Curran and Blackburn, 2001) and holds the potential for generating additional retirement income by creating a business that can be sold (Clarke and Holt, 2010). Further, and in contrast with younger potential entrepreneurs, some suggest that older entrepreneurs are relatively freed of the constraints associated with raising a family such as a need for security tempering risk-taking entrepreneurial instincts and that this sense of unconstrained stability combines with accumulated wealth, experience and social capital that can be invested in business ventures (Jayawarna et al., 2013; Kautonen, 2008; Singh and DeNoble, 2003). Perhaps as a result of this, there are suggestions that ventures initiated by older people enjoy longer lifespans than ventures started by younger age groups (Storey and Cressy, 1996).

Of course, 'older entrepreneurs' represents a diverse range of people. For example, while entrepreneurship can be used to achieve social ends beyond wealth-creation (Harding and Cowling, 2004), those who are socially disadvantaged 'do not enjoy such entrepreneurial advantages as associated with older workers more generally compared to their younger counterparts' (Kautonen, 2008, p.89; see also Curran and Blackburn, 2001; Kanfer and Ackerman, 2004; Phillipson, 1982), despite their being a frequent focus for entrepreneursupport programmes. Further, entrepreneurship may not be a positive step for all older workers and some 'reluctant entrepreneurs' (Galbraith and Latham, 1996; Singh and DeNoble, 2003) may turn to self-employment as a last resort and with a low-risk attitude in response to the dangers of failure and unemployment (Hinz and Jungbauer-Gans, 1999; 
Kibler et al., 2011). This may be particularly true where ageism precludes employment opportunities in the labour market and difficulties in locating or identifying support such as mentors (Kibler et al., 2011; Wainwright et al., 2012). The juxtaposition of conceptions of age and risk in the context of an ageing body and pending retirement permits the construction of a discourse implying that 'older workers [are] unlikely to be successful entrepreneurs; and therefore should be discouraged from attempting it' (Ainsworth and Hardy, 2008, p.398). The prospects for older entrepreneurs therefore appear uncertain.

The dangers of treating older entrepreneurs as a homogeneous group also relate to other forms of disadvantage individuals may face. Whilst the entrepreneurs participating in the present study are both white males we do not suggest the discounting of other social and demographic factors that have been considered in the broader literature on entrepreneurship (Ogbor, 2000) or older workers more generally such as gender (Loretto and Vickerstaff, 2011), class (Phillipson, 1982), ethnicity (McNair, 2010; Moody, 2002), occupational background and qualifications (Gould, 2006; McNair, 2006) or geographical location (Dalen et al., 2009). For example, there may be gender imbalances around issues such as the caring roles disproportionately fulfilled by women and impacting on their ability to start up a business (Kibler et al., 2011). However, by moving away from treating older entrepreneurs (or any subgroup we might construct such as older female entrepreneurs) as a homogeneous group, we focus on depth and a nuanced understanding of individual experience.

Understanding more about the day-to-day experiences of people practising entrepreneurship in the context of pending retirement can provide insights into the tensions, 
[Type here]

pitfalls and successes that may await others taking this path. The shortage of personal accounts in studying self-employment for those contemplating retirement or with such expectations thrust upon them constrains serious consideration of this important topic to a level of macro scale policy discussion, for example of the causes of discrimination and the viability of policies to promote older entrepreneurship. However, the relatively limited attention paid to practitioners' own accounts of their experiences reflects the study of entrepreneurship more widely (Morris et al., 2012).

Gaining an appreciation of the everyday lived experience of entrepreneurship, including its attendant ups and downs, professional challenges and personal conflicts is an important step in moving beyond simplistic visions of heroic entrepreneurs (Down, 2006) and appreciating the range of influences impacting upon entrepreneurs and the choices they make (Baron, 2000; Cardon et al., 2012; Doern and Goss, 2013; Jayawarna et al., 2013; Shepherd, 2003). From the detailed accounts of what it is like to be an older entrepreneur in the context of pending retirement, professionally and personally, we explore the complex interactions of their motivations, life-work and interpersonal relationships and relationships with their respective business. These are outlined in our findings and their implications then discussed in detail. We will first describe our methodological approach.

\section{Studying the Lived Experience of Older Entrepreneurs}

\section{Accounts of Entrepreneurship}

We will focus on two longitudinal, detailed case studies to explore the everyday lived experiences of older entrepreneurs in the context of pending retirement. Our exploratory, 
inductive case studies of Thomas and Edward were guided by the broad framework of our interest in the challenges faced by these individuals in their entrepreneurial endeavours (Miles, 1979). Our semi-structured approach to interviewing allowed us to follow lines of interest that developed within our interviews and for us to be partially guided by the participants.

The generation and analysis of narrative accounts (Polkinghorne, 2007), provides a research approach that embraces the complexities of qualitative interviews and the accounts that are co-produced between the interviewer and interviewee (Larty and Hamilton, 2011; Riessman, 2001). A narrative approach sensitises us to the connections between past, present and future (Riessman, 2001) and allows us to explore areas such as sensemaking, power and identity through an analysis of the accounts generated in the research encounter. This includes, for example, the ways in which participants draw upon past experience and plans for the future (Down, 2012) that may differentiate older entrepreneurs, especially in the context of pending retirement. Further, it allows us to attend to their interpersonal context (Jayawarna et al., 2013) and interaction with potential barriers such as ageism (Down 2006) and dominant socio-historical discourses around self-employment, age and retirement (Ainsworth and Hardy, 2008; Mallett and Wapshott, forthcoming). Narrative approaches therefore provide a valuable methodology for studying entrepreneurs (Larty and Hamilton, 2011).

We must acknowledge the social construction of their narrative accounts within the context of interviews with researchers who are not self-employed and are much younger than themselves (both researchers were in their mid-30s). There is a degree of performance that 
is inescapable in the production of interview material that, we suggest, is better to engage with and to form part of the analysis, than to attempt to remove or avoid. Further, while the accounts produced within the chapter are, by necessity, selected, edited and framed by the authors, we suggest that interviews are inherently (inter)subjective, that no 'objective', impersonal record of participants' lived experience is accessible or liable to representation in an academic article (Alvesson, 2011; Kvale and Brinkmann, 2009). A narrative approach, in which we present participants' accounts as far as possible in their own words to privilege voices that have thus far been underrepresented in the literature, embraces this coconstructed nature of the empirical material and allows us to explore entrepreneurs in context (Clarke and Holt, 2010; Larty and Hamilton, 2011).

Research participants for this study were selected from existing contacts who fitted both common definitions of an older entrepreneur, as someone starting a business when aged 50 or older (Kautonen, 2008) and self-identified as working in a context of pending retirement. These individuals were also interesting in terms of our study because of their respective stages on their entrepreneurial journeys. Thomas was leaving his employer and setting up on his own while Edward was considering stepping away from his venture after more than ten years. These differences are not to suggest cross-case comparison of like cases but two different and interesting case studies that might help to elucidate the issues encountered by these men experiencing entrepreneurship in the context of their pending retirement.

Edward was an existing contact from a previous research project while Thomas was known socially by the second author. We suggest that the pre-existing and developing relationships between participants and researchers that emerge from in-depth longitudinal research are 
not only an inevitable part of the co-constructed nature of the material but also add to the detail and depth of insight that can be achieved. Our pre-existing relationships also allowed us to begin the research process when Edward and Thomas were experiencing particular challenges and to return over a period of time to conduct further interviews at key points, rather than relying on later reflections of past experiences. Our semi-structured interviews and other interactions, such as occasional social events, engaged with the difficulties and failures they had each encountered, revelations that might be more readily relayed to trusted associates than complete strangers (Illingworth, 2006).

These intensely personal accounts suggest deeply held hopes and fears, provoking some uncomfortable reflections between the researchers. On the one hand, these accounts provided us with rich empirical material that would aid our understanding, but, on the other hand, our participants were going beyond a typical researcher-researched division, taking us into their confidence and into some ambiguity over the morality of our project (see Bourdieu, 1999; Chase, 2011; Moss, 2004). At times, as researchers, our discussions around the interviews concerned whether we had 'gone too far'. However, we must not overstate our power-position as interviewers or present our participants as 'uniformly passive or powerless' (Leatherby, 2002: 4.5). For example, as we concluded our first formal interview with Thomas, he proceeded to provide us with unprompted 'feedback' on how he felt we had conducted the interview. Further, both Edward and Thomas reported on several occasions how personally useful they found the process.

The interviews, conducted over seven years with Edward and 18 months with Thomas, were supported by informal catch-ups via phone, email and text as well as social events and 
informal visits to their workplaces. Interviews with Edward involved visiting him in three different locations, as he moved his offices around the city, while, with Thomas, meetings took place in or around railway stations as he travelled between meetings. Engaging with Edward and Thomas through repeated encounters over a significant period of time added nuance to our understanding of their experiences, capturing, for example, shifts in attitudes both towards their ventures and people around them. Longitudinal approaches to studying entrepreneurs, with multiple points of contact, are important for accessing lived experience (Cardon et al., 2012).

Given the sensitive and highly personal nature of the experiences related to us by Edward and Thomas we have created pseudonyms for them and the names of their companies (ScirCo and NouCon respectively) along with keeping other potentially identifying detail vague. Both Thomas and Edward are based in the UK, outside London.

\section{Analysing Accounts and Generating Understanding}

The process of gathering accounts over multiple interviews permitted thorough reviews of interview transcripts and other sources between encounters. Memos and notes were shared between the researchers to indicate topics worth introducing or revisiting on subsequent interviews. More formally-structured analyses of Thomas and Edward's accounts were then conducted adopting an inductive theme analysis (Boje, 2001).

In the first instance all interview, observation and documentary forms of information were reviewed in full by both authors in terms of within-case analysis. This helped to highlight where the opinions the participants expressed altered or contradicted views expressed in 
other interviews. Rather than try to smooth out these 'discrepancies' we explored the context and purpose of these opinions. This provided us with a story (or more accurately several fractured, overlapping and contradictory accounts) of their experiences as entrepreneurs in the context of their pending retirement.

Using the qualitative data analysis tool NVivo8, Thomas and Edward's accounts were coded inductively by the first author. Thematic codes were created and defined at points of emphasis within the accounts and of relevance to our research focus. The analysis software allowed us to code the empirical material without removing extracts from their original context. Both authors then jointly reviewed the extracts using codes to compare the cases. For example, with the code 'Personal Tensions' we examined how Thomas discussed where the involvement of others in his nascent enterprise had created tensions and compared this to Edward's views and experience. The purpose of this exercise was to aid understanding of both cases by comparing the ways in which Thomas and Edward's reported experiences were similar or different, rather than just identifying where similarities or differences existed (Gibbs, 2007). Our aim was to characterize, rather than categorize these accounts (Somers, 1994).

Working with our initial codes, alongside the full accounts and our focus on their lived experience, we refined our codes into three key themes that emerged in the accounts we had gathered, accepting the interconnectedness of each of their accounts. The three themes represent key experiences of Thomas and Edward and relate to motivations for entrepreneurial activities, life-work and interpersonal relationships, and their relationships with their business. We use these themes to structure our presentation of findings and draw 
out their interconnectedness in our discussion as we explore how founding and running a business in a context of pending retirement can be subject to complexities and degrees of risk that have a bearing on the lived experience of entrepreneurship.

\section{Findings}

Before exploring the themes that emerged from Thomas and Edward's accounts, it is valuable to outline their personal stories, giving a sense of their individual circumstances and a context for accounts of their experiences. These stories are an amalgam of their personal descriptions, their résumés and other related sources provided to us.

\section{Thomas}

Thomas started his successful career in the media industry. He spent about 15 years in media, although he did take some 'time out' while he considered following in the family retail business. Over the next 20 years Thomas worked in a variety of consultancy roles, both on his own and with organizations, including five years with a major, international professional services firm. His initial experience of self-employment began with a mediabased consultancy firm but developed to focus more on change management and trainingprovision. His most recent employment was with a small international consultancy firm (BouCon) and, at the start of the research period, he was working on an occasional basis for this firm. Meanwhile he was seeking funds to buy out the line of business he was working in and set out on his own (NouCon). Now in his mid-fifties, Thomas' decision to return to self-employment was described in terms of wanting 'to be a number one not a number two.' He had previously been attracted to working with a young rising star, seeing himself in a 
mentor-type role facilitating the fulfilment of their potential. But, as the interviews revealed, the prospect of his looming retirement had thrown his career to-date into sharper relief, raising concerns about his achievements.

Our first formal interview with Thomas took place on his way home from a meeting intended to secure the finance he required but in which this tentative deal had fallen through. Finding financial backing for the buyout proved problematic through a large part of the research process, representing a source of tension and annoyance. In the meantime, Thomas did not feel very motivated and was frustrated by his relationship with BouCon, suggesting that they expected him to prove himself in areas that should not be necessary given his previous experience. During the following year, Thomas' business venture failed to become fully sustainable and, whilst finding a financial partner, Thomas attributed the apparent failure of the venture to a lack of fit between himself and this potential colleague. Currently, Thomas is setting up a new business drawing on a range of his previous experience.

\section{Edward}

Edward started ScirCo following a successful career at a Blue Chip company. He had progressed from being a sales representative to heading up international recruitment for a range of business units before an organizational merger provided an opportunity to assess his life and career, prompting his decision to pursue voluntary redundancy and establish ScirCo. ScirCo's first and, following gradual business changes, now only client is a business unit sold off as part of the company merger. Edward therefore knows the client- 
business intimately. Over ScirCo's 11 years in operation, employee numbers peaked at seven while, at the time of writing, there are two fulltime employees. The business has been profitable, providing Edward with an income exceeding what he could expect to earn as an employee elsewhere.

Interviewing Edward over several years revealed how the performance of his business impacted upon him emotionally. As he began to enter a phase of contemplating retirement and the closure of the business, he acknowledged the emotional bond he feels with ScirCo. Edward came across as particularly vulnerable to self-doubt and uncertainty about his achievements. Despite the objective evidence of a healthy income, executive car and profitable business, Edward seemed hounded by doubts over whether he could have achieved more. In measuring his relative success, Edward often chose unrealistic comparators such as the superstar entrepreneur investors on popular TV programme Dragons' Den.

In 2004 he explained how, if he decided to close down the business, he could become an employee once again. However, by 2011, Edward appeared unable to contemplate such a thought. Likewise, the purpose of the organization had shifted over time from pursuing growth and releasing Edward from operational involvement to reducing costs, maximizing his returns and giving him something to do with his time. As state pension age appears on the horizon, Edward is again contemplating his role and the future of the business. While he is reluctant to close it, his current staff seem unsure about taking it on and Edward's adult children are not in a position to do so. Furthermore, any decision to retire would leave 
Edward at something of a loose end. For now, however, Edward is predominantly focused on building his pension savings.

Consistent with the inductive nature of our study, here we present three themes that emerged from our reading of Thomas and Edward's accounts. We present their accounts with minimal commentary but attempt to set the extracts in context. We then explore the insights and implications provided by these extracts in the subsequent Discussion section.

\section{Drivers and Motivations for Entrepreneurial Activities}

In our discussions with Thomas and Edward, each expressed a range of different drivers behind their desire to create a business. Both articulated a sense in which establishing a business of their own, following success in corporate environments, reflected a desire to build or grow something. But their motivations were also revealed as more complex than this, particularly in the context of pending retirement. For Thomas there were motives around finance and a sense of achievement behind his desire to set up his own business, adding a degree of urgency to his goals:

There is also a real desire to make some serious dosh. I have always been able to earn a high income but have managed successfully not to make the big bucks... and it sounds crass but actually it is quite an important driver for me at this stage.

And there is also something around as well, is that the nature of my career has been such that I have you know followed my heart rather than the bank balance. A large 
part of my early career was in [employer] and there is a gaping hole in [employer] pension fund. And I am now 54, coming up to 55, and there is a limited number of years I can fix my pension provision. And I am not planning to die when I am 66. So there is a real issue at the moment of saying well how do we...how do I make sure that I am fully provisioned for what I hope is a long and healthy and happy retirement; or a long retirement where I can afford the choices to decide whether I go into that home or that one?

So there is a whole set of kind of things which I kind of...I am scrabbling around with both in terms of provision and also in terms of I guess the satisfaction factor. I have got all these skills, this is my...it feels like this is my last chance of really pulling it all together and doing something significant. So there is a kind of a legacy element in there as well.

Thomas' motivations were discussed in a context of wanting to prove something. On one occasion he talked in subdued terms about his experience at his last employer where he felt marginalized, possibly on account of his age, and was, as he saw it, 'set up to fail'.

A younger version of me wouldn't understand that, despite the acquisition of more experience and self-development and learning, two things are going on. One there is a new creature emerged called a grandfather and with an awareness of mortality and, you know, endgames in sight. And there is also a perception that the world no longer sees me as the 40 -year-old who is going places. But as the 50-somethingyear-old who is making up the numbers. And I think one of the things...the painful 
things I have experienced in the past few years is that if you plant yourself in the wrong part of the garden you start to wither. And I found that a really painful process.

For Edward, financial worries were less of a concern. However, this did not leave his considerations of his future as unproblematic and it was apparent that the motivations for running his enterprise had altered with the prospect of reaching the state retirement age. Some of the pressures and tensions involved in running his own business had eventually led to a renewed attitude, leading him to manage the business in a relatively stress-free, profitable manner:

I guess my view has sort of changed as we have gone through...initially it was you know providing me with a reasonable income, fine. And then I got to the stage where...when we had all the staff and everything, what I wanted to try and do was to build the business so that when I do retire someone else could run it. Or I could sell. And what you tend to find is that whilst you have this sort of passion and commitment and all that sort of stuff, staff generally don't... You know now I don't really want all that hassle and aggravation that staff give you really.

Edward's approach to running his business, how he conceived of his goals and judged his successes, was constructed in relation to expectations associated with pending retirement. The point of retirement is treated as a moment of judgement: will he have created a sustainable business that can survive his leaving the business?

\section{Life-Work Tensions and Interpersonal Relationships}


In considering retirement as a process with associated normative expectations rather than as a discrete event, there is clearly an important role for interpersonal relationships and significant others, although these topics have received little attention in the literature on older entrepreneurship. Both Edward and Thomas talked frequently about their business ventures in relation to their wider home and social lives. Raising this issue in several interviews, Edward implied that a personal, romantic relationship was now something he wished he had placed a higher priority on:

You know your outlook on life does change as you...I guess you know one of my regrets is that the last ten years I haven't really had a relationship. You know so I have lost ten years from that perspective, so not putting everything into the business because that is not the case but I guess you could...I mean you know obviously I can't date [job applicants], I can't date anyone at [client]. So that does then limit your sort of exposure to people. You know so of course that is a disadvantage of you know running your own business. You know staff-wise you have got to be a bit...you know always keep them at arm's length you know. I guess it has been one of the sort of down sides I guess of...So I guess, you know you always have to sort of be on parade.

While Edward was clear that his lack of romantic involvement was not entirely owing to his business commitments, the nature of his role constrained opportunities that might otherwise have been available. The assumptions associated with a pending retirement, that he would settle down in a normative form of domestic bliss, repeatedly acted as a catalyst for difficult personal refection. On an earlier occasion, he reflected ruefully: 
You know, I am totally my own boss. I do exactly what I want, when I want and you know that perhaps is not a good thing in some respects is it?

In talking to both Edward and Thomas, it also appeared that family caring responsibilities were still very relevant, merely in an altered form rather than disappearing. Edward's desire to help his daughter's family through his business presented him with various challenges balancing his role as a father and grandfather with that of running a profitable business, while Thomas discussed a range of recent personal experiences from the death of his mother to the birth of his first grandchild in shaping his views on establishing his own enterprise. Despite the strains these events had put on Thomas and his family, he resolved to look upon things 'philosophically':

... as opposed to most other periods in my life when new things have happened in my career this has happened in a much more balanced way that says this is all about what is happening to me in my life at this stage. And I wouldn't be doing this at this stage in my life if I hadn't done some of the things I have done in the past. So it feels like part of a whole life story.

Elsewhere in Thomas and Edward's accounts, family loomed large in the form of fraternal tensions. Considering Thomas' life story, in terms of the interviews and his personal planning document, it seemed that he was also driven to achieve some sense of legitimacy or acceptance from his successful older brothers who, having built careers in the Civil Service were now retired and benefiting from relatively generous and secure pensions. For 
Thomas, his need to keep working reached beyond his bank balance, with financial sufficiency becoming a marker of achievement against how he felt his brothers viewed him.

Edward's relationship with his older brother was particularly complex when personal and business issues were mixed. As Edward had grown out of his brother's shadow, their relationship had changed:

I guess I always used to, when I was younger, seek sort of support from my brother [...] But I think once I sort of got past that the relationship we have is a sort of a funny relationship I suppose you know [...] I listen to what they have got to say and then make my own decision. You know which I guess is...it is fair. You know some people would say well I would trust my life with the advice that you give me but I would always be a bit sceptical I guess

Again, pending retirement provided some kind of marker and a pressure on certain types of relationship. Further, these older entrepreneurs were certainly not as free and without responsibility as they have often been presented in the literature, experiencing pressures to support both adult children and ageing parents. These perceived responsibilities created pressures both financially and in terms of their time. However, within the interview accounts, their strongest bonds often appeared to be with the businesses themselves.

\section{Relationships with the Business}

Beside these interpersonal relationships, our discussions with Thomas and Edward revealed interesting relationships with their business ventures and the act of entrepreneurship. 
Although reporting distinct experiences in many ways, not least because, while for Thomas the outlook was one of possibility, Edward was contemplating closing this chapter of his life, both older entrepreneurs had a strong emotional relation to their ventures.

Thomas felt that business and entrepreneurship was 'in his blood'. His relationship with NouCon went beyond earning 'serious dosh' or a sense that he has one 'last chance of really pulling it all together and doing something significant'. The idea of entrepreneurship had taken on significance for Thomas; he conveyed a belief that through this venture he will be able to achieve extraordinary, visible success. The venture is seen as a means of redemption, proving that he is not just 'making up the numbers' and that, at heart, he is a success.

When you take all the other stuff away, [what] is the essential [Thomas] stuff? The impact that I have is both inspiring large numbers of people and producing materials and programmes that have that impact $[\ldots]$ it's the reconnecting with that that says, you know, what does success feel like? Yes it feels like a big cheque at the end of it. But it also feels like people saying to me 'that was brilliant'. And I have got a profound belief that actually I am at my best when I am enjoying myself. And [previous employers] haven't been getting that in the past couple of years, is basically what it has felt like.

Yet, despite all of his experiences, Thomas, found himself in some ways pushed into entrepreneurship in the context of his pending retirement. Perceiving ageism in the 
workplace, his need for pension provision and to prove his achievements, Thomas faced uncertainty about how to manage this stage of his career and life:

There is also a thing about, you know, it is a complex age that nobody... well very few people write about this age. You know being a teenager you can pick up thousands of books, being a child in...early stages of... and actually you get to this stage and who the fuck is actually writing about the transitions of people who either have had a successful career and now want to do something different? Or people who have managed not quite to be as successful or people who have just you know stagnated? And it is an interesting area and particularly in a world where it is likely that my generation, certainly your generation are not going to be retiring at 65 . Chances are you know we are going to be working on...

As he considers the context and changing nature of retirement, Edward's emotional attachment to his venture also revealed uncertainties and conflicts. On the one hand he enjoyed the status afforded by running his own business and the benefits provided by ScirCo's profits.

I am a bit materialistic I suppose in terms of what I have you know ...car (INT: Big BMW!) Big BMW. But then you know it is the same with the offices and the staff and then it is a bit sort of you know coming in...you know boardroom with a board table and meetings and all this sort of stuff.

Nevertheless, he explained that contemplating the business as he focused on retirement brought home the emotional 'stake' he had built up in ScirCo. 
You don't sort of spend you know the best part of the last ten years you know and just pull the plug. You know I suppose that is probably why I haven't done it you know.

Although referring to quite different experiences, both Thomas and Edward discussed the personal emotional stake they held in their respective ventures. The nature of these emotional investments made their stories emotional in themselves. As the research process came to an end Thomas was optimistic about new, locally-focused ventures and Edward concentrated on planning his retirement financially and finding something to do with his time.

\section{Discussion}

Existing studies of older entrepreneurs have engaged with the important tasks of identifying the prospects for entrepreneurship as a route out of discrimination and disadvantage in regular forms of paid employment (PRIME, 2011) and the barriers facing those who may seek to pursue this style of work (Kautonen et al., 2008; Kibler et al., 2011). While this important research should continue, we argue that it can be enriched by incorporating practitioners' personal accounts of their lived experiences. Our findings reveal that, despite the advantages older people in the context of pending retirement might appear to have in starting a business it is a messy, complex and highly emotional process.

Thomas and Edward's entrepreneurial ventures appear to have avoided the overt age discrimination reported elsewhere in the literature. However, their experiences do still highlight the complexity associated with entrepreneurship at this stage in life. Whereas 
those starting a business later in life may, in some senses, appear to benefit from financial resources, limited family responsibilities, accumulated stocks of human capital and experience (Jayawarna et al., 2013; Kautonen, 2008; Singh and DeNoble, 2003), Thomas and Edward's accounts reveal how these things cannot be taken for granted. Even while representing, in different ways, stereotypical examples of who might productively engage in entrepreneurship (white middle-aged men who have enjoyed successful and well-paid organizational careers, grown up children and so on), Edward and Thomas' accounts portray an altogether more complicated, ongoing process.

Spending time with Thomas and Edward, we were struck by the shifting nature of their respective narratives: sometimes upbeat, ambitious and planning the next phase of their business; at other times downbeat and uncertain of their prospects. These shifts in mood and perspective on their ventures highlighted just how 'messy' the process of entrepreneurship in a context of pending retirement can become. Thomas and Edward expressed a number of drivers for their business ventures (Birley and Westhead, 1994; Jayawarna et al., 2013) which appeared to vary over time, overlap and at times contradict. Alongside the anticipated drivers of securing a financial future for themselves and their families, they saw in their ventures an opportunity to test themselves, to see whether they could build a successful business (Jayawarna et al., 2013). The context of pending retirement created certain expectations and these types of driver were often related to their career stage, as a 'final opportunity' or as necessary to fulfil earlier potential. But this was never straightforward. For example, Edward's ambition shifted between growing a business and reducing staff numbers in search of a quiet life, while Thomas moved quite 
comfortably between emphasising financial success and proving himself as his main motivation.

Such shifts and multiplicity arose as our participants evaluated and re-evaluated what they had achieved to-date in their careers and more widely and what they desired from their business ventures. Edward, who had assured his financial security, discussed how he responded negatively to perceived criticisms of his business and the rewards it had brought him. Despite his financial success, he was still able to lower his mood by wondering whether he had really achieved enough when comparing himself with a handful of elite entrepreneurs. Thomas was in an altogether more tricky position because his continually shifting focus expended energy without making progress and time was running out against his planned schedule. For neither Edward nor Thomas was there any suggestion of finding ways to accommodate multiple or contradictory goals or desires. Rather, their energies appeared to ebb and flow between these alternatives, indicating the influence of context on the 'contingency and dynamism' of their motivations (Jayawarna et al., 2013: 35).

Contrary to the sense of stability suggested in some of the older entrepreneur literature (for example, Singh and DeNoble, 2003), the various motivations described by our participants at different times were further complicated by changes they were each experiencing in their personal lives. There were a range of relationships, from personal, family and social in addition to those with stakeholders and customers, that impacted on the ventures and how the older entrepreneurs sought to manage their businesses. Thomas was now a grandparent with a seriously ill mother-in-law while Edward, already a grandparent and trying to support his daughter's family, was starting to regret not directing energies into a romantic 
relationship over the years invested in his venture. Both Thomas and Edward were coming to terms with personal challenges that demanded significant attention. Both spoke in terms of personal discovery and the negotiation of this process with significant personal contacts and in relation to the business. Such searches and negotiations frequently appeared at odds with the picture presented in much of the literature describing older entrepreneurs as freed from family constraints.

Entrepreneurs are not isolated individuals but must be understood, instead, as embedded within networks of interrelationships, of business, personal and emotional concerns that shape their scope for action and their business decisions (Clarke and Holt, 2010; Doern and Goss, 2013; Jayawarna et al., 2013). For example, while Kautonen (2008, p.10) perceives 'the removal of family obligations at an older age' (our emphasis), through Edward and Thomas we see a change in family obligations and relationships rather than their removal. The continuing, albeit altered, demands of family life still require attention and adjustment as these ongoing relationships continue to develop. For example, Edward, a single divorcee with no mortgage and grown-up children, appears to represent an ideal case of this unencumbered, prestige entrepreneur (Jayawarna et al., 2013). As we have seen, however, such an interpretation of freedom overlooks the continuing obligations to family members and pays insufficient attention to the possible downsides of personal independence.

The older entrepreneurs in our study also discussed important fraternal conflicts and the influence these exerted on their working lives. The tensions in the relationships Edward and Thomas both had with their brothers revealed the degree to which personal lives 'encroach' on professional lives. The brothers of both Edward and Thomas lurked in the background of 
their ventures to varying degrees and seemed to shape these entrepreneurs' own view of their businesses. While Edward felt his brother was in some ways jealous of his achievements, Thomas was especially driven by a desire to prove to his brothers (and himself) that he was a success. As the end of their careers was perceived as approaching, these sources of affirmation seemed to take on great importance. Both Edward and Thomas had been successful in general terms but there was still a sense of needing to achieve or to prove something not only to themselves but also to significant others in their lives.

In addition to the social reckoning that looms at the end of their working lives, Edward and Thomas were also aware of the very real prospect of financial reckoning and its impact on their personal lives. While Edward was financially secure in his business and savings, Thomas was coming to terms with a significant hole in his pension provision (Vickerstaff and Cox, 2005). Although Thomas may not be a typical 'reluctant entrepreneur' (Singh and DeNoble, 2003, p.218; see also Jayawarna et al., 2013) being forced into entrepreneurship, he lacks the financial base to act as collateral that is often assumed to be possessed by older entrepreneurs (Singh and DeNoble, 2003; Storey and Cressy, 1996). As issues around shortfalls in pension provision emerge for even successful and relatively well-resourced individuals, the notion of older entrepreneurs with stable resource bases may need to be rethought (see also Kibler et al., 2011).

The significant emotional investments Edward and Thomas have made in their ventures highlights how the stakes in ventures can far exceed any monies invested and expands upon the relevance of an individual's life course (Down, 2012; Jayawarna et al., 2013). Although financial motivations might represent significant and tangible drivers of older peoples' 
entrepreneurial ventures, a range of emotional drivers as well as socio-emotional barriers also appear to be at work (Cardon et al., 2012; Doern and Goss, 2013), many of which appear heightened in the emotional context of pending retirement. The size of the financial and emotional stakes mean that the consequences of conceding failure are potentially traumatic from a personal as well as a financial perspective (Shepherd, 2003) at a time when the entrepreneur might have few options for recovering either position (Hinz and Jungbauer-Gans, 1999; Kibler et al., 2011). This, in turn, might influence their perceptions of, and attitudes towards, risk. Younger entrepreneurs might be able to downplay the degree of such risks, believing that financial ruin might be recovered by recourse to paid employment (and time to (re)build entrepreneurial ventures) but this path is already problematic for those who are in a context of pending retirement. From Edward and Thomas' accounts we must therefore not lose sight of the significant emotional stakes that older entrepreneurs might hold in their businesses and the complex messiness these ventures involve. In light of these high stakes, the prospects for entrepreneurs in a context of pending retirement require further careful consideration.

\section{Conclusion}

Older entrepreneurs are a relatively new and under-researched topic. There are key gaps in understanding around the challenges that entrepreneurs in the context of pending retirement face, and a lack of explorations of their individual and interpersonal lived experiences of the start-up and running of their enterprises. The normative effects of retirement exert influence long before paid (self) employment is left for good and these effects reach back 
into working lives in forms such as pension planning and assumptions over what older people want from work and for how long.

This chapter has presented two interesting, longitudinal case studies from the UK. In presenting the voices of these older entrepreneurs we have attempted to convey the lived experiences of Thomas and Edward, using a qualitative, narrative approach to locate the 'person' more prominently in the discussion of entrepreneurship in the context of pending retirement. Gaining an appreciation of the lived experience of entrepreneurship, including its attendant ups and downs, professional challenges and personal conflicts has been argued as important to move beyond simplistic visions of heroic entrepreneurs (Down, 2006) and to appreciate the range of influences impacting upon entrepreneurs and the choices they make (Jayawarna et al., 2013).

We have sought to characterize, not categorize these individuals but several important themes emerged from our research. Thomas and Edward's accounts highlight how their ventures are located within broader contexts that include evolving family obligations and tensions, financial uncertainties around pensions and ongoing personal objectives for achievement through their business as the prospect of retirement looms. Contrary to a dominant view of older entrepreneurs as advantaged by financial resources, limited family responsibilities, accumulated stocks of human capital and experience (Jayawarna et al., 2013; Kautonen, 2008; Singh and DeNoble, 2003), the existence and interaction of the challenges we have identified highlight how the processes of entrepreneurship in the context of pending retirement can be messy, complex and highly emotional. 
[Type here]

This is important because, without a sense of practitioners' personal accounts of their experiences, the prospects for older entrepreneurship can only be partially understood, with implications for the effectiveness of government and charity policies that look to entrepreneurship to address the many problems facing those living in a context of pending retirement (see for example, PRIME, 2011). Echoing recent debates in the entrepreneurship literature more widely, we suggest that overlooking the everyday accounts of entrepreneurs risks hampering our understanding of the everyday experience and processes of entrepreneurship (Baron, 2000; Down, 2006) and, in doing so, fail to characterise the changing nature of challenges such as those relating to family responsibilities. As studies continue to develop the emerging research base around older entrepreneurs, we hope that space can be found for the voices of those who experience these messy, complex and highly emotional processes first hand.

\section{References}

S. Ainsworth and C. Hardy (2008) 'The enterprising self: An unsuitable job for an older worker', Organization, 15(3), 389-405.

M. Alvesson (2011) Interpreting Interviews (London: Sage).

R. A. Baron (2000) 'Counterfactual thinking and venture formation: the potential effects of thinking about "what might have been", Journal of Business Venturing, 15(1), 79-91. 
[Type here]

R. Beckhard (1977) 'Managerial careers in transition: Dilemmas and directions', in J. van Maanen (ed.) Organizational careers: Some new perspectives (London: John Wiley \& Sons).

S. Birley and P. Westhead (1994) A taxonomy of business start-up reasons and their impact on firm growth and size. Journal of Business Venturing, 9(1), 7-31.

D. M. Boje (2001) Narrative Methods for Organizational and Communication Research (London: Sage).

P. Bourdieu (1999) 'To the reader', in P. Bourdieu et al., The weight of the world: Social suffering in contemporary society (Cambridge: Polity Press).

M. S. Cardon, M-D. Foo, D. Shepherd and J. Wiklund (2012) 'Exploring the heart: Entrepreneurial emotion is a hot topic', Entrepreneurship Theory and Practice, 36(1), 1-10.

S. E. Chase (2011) 'Narrative inquiry: Still a field in the making', in N. K. Denzin and Y. S. Lincoln (eds.), The SAGE Handbook of Qualitative Research $4^{\text {th }}$ ed. (Thousand Oaks, CA: Sage).

J. Clarke (2011) 'Revitalizing entrepreneurship: How visual symbols are used in entrepreneurial performances', Journal of Management Studies, 48(6), 1365-1391.

J. Clarke and R. Holt (2010) 'The mature entrepreneur: A narrative approach to entrepreneurial goals', Journal of Management Inquiry, 19(1), 69-83. 
[Type here]

J. Curran and R. Blackburn (2001) 'Older people and the enterprise society: Age and selfemployment propensities', Work, Employment and Society, 15(4), 889-902.

H. P. van Dalen, K. Henkens and J. Schippers (2009) 'Dealing with older workers in Europe: A comparative survey of employers' attitudes and actions', Journal of European Social Policy, 19(1), 47-60.

E. Dini (2009) 'Older workers in the UK: Variations in economic activity status by sociodemographic characteristics, household and caring commitments', Population Trends 137 (London: Office for National Statistics).

R. Doern and D. Goss (2013) 'From barriers to barring: Why emotion matters for entrepreneurial development', International Small Business Journal, 31(5), 496-519.

S. Down (2006) Narratives of enterprise: Crafting entrepreneurial self-identity in a small firm. Cheltenham (UK: Edward Elgar).

S. Down (2012) 'Evaluating the impacts of government policy through the long view of life history', Entrepreneurship \& Regional Development, 24(7-8), 619-639.

D. J. Ekerdt (2010) 'Frontiers of research on work and retirement', Journal of Gerontology: Social Sciences, 65B(1), 69-80.

M. Freedman (2007) Encore: Finding work that matters in the second half of life (New York: PublicAffairs). 
[Type here]

C. Galbraith and D. Latham (1996) 'Reluctant entrepreneurs: Factors of participation, satisfaction, and success', Frontiers of Entrepreneurial Research 1996, Babson College Entrepreneurship Research Conference: Babson Park, Massachusetts.

G. Gibbs (2007) Analyzing qualitative data (London: Sage).

R. Gould (2006) 'Choice or chance - late retirement in Finland', Social Policy \& Society, 5(4), 519-531.

R. Harding and M. Cowling (2004) 'Social Entrepreneurship Monitor UK 2004' (London: Global Entrepreneurship Monitor / Foundation for Entrepreneurial Management).

T. Hinz and M. Jungbauer-Gans (1999) 'Starting a business after unemployment:

Characteristics and chances of success (empirical evidence from a regional German labour market)', Entrepreneurship \& Regional Development, 11(4), 317-333.

N. Illingworth (2006) 'Content, context, reflexivity and the qualitative research encounter: Telling stories in the virtual realm', Sociological Research Online, 11(1). Retrieved April 26 2014, from http://www.socresonline.org.uk/11/1/illingworth.html

D. Jayawarna, J. Rouse and J. Kitching (2013) 'Entrepreneur motivations and life course', International Small Business Journal, 31(1), 34-56.

R. Kanfer and P. L. Ackerman (2004) 'Aging, adult development, and work motivation', Academy of Management Review, 29(3), 440-458. 
[Type here]

T. Kautonen (2008) 'Understanding the older entrepreneur: Comparing third age and prime age entrepreneurs in Finland', International Journal of Business Science and Applied Management, 3(3), 3-13.

T. Kautonen, S. Down and L. South (2008) 'Enterprise support for older entrepreneurs: The case of PRIME in the UK', International Journal of Entrepreneurial Behaviour \& Research, 14(2), 85-101.

E. Kibler, T. Wainwright, T. Kautonen, and R. Blackburn (2011) '(Work)Life after work: understanding barriers to older entrepreneurship in London', Paper presented at the 56th Annual ICSB World Conference; 15 - 18 June 2011, Stockholm, Sweden.

J. P. Kotter (1985) Power and influence: Beyond formal authority (New York: Free Press).

S. Kvale and S. Brinkmann (2009) InterViews: Learning the craft of qualitative research interviewing (London: Sage).

J. Larty and E. Hamilton (2011) 'Structural approaches to narrative analysis in entrepreneurship research: Exemplars from two researchers', International Small Business Journal, 29(3) 220-237.

G. Leatherby (2002) 'Claims and disclaimers: Knowledge, reflexivity and representation in feminist research', Sociological Research Online, 6(4). Retrieved April 26, 2014 from http://www.socresonline.org.uk/6/4/letherby.html 
[Type here]

W. Loretto and S. Vickerstaff (2011) 'The relationship between gender and age', in E. Parry and S. Tyson (eds.) Managing an age diverse workforce (Basingstoke: Palgrave Macmillan).

O. Mallett and R. Wapshott (forthcoming) 'Making sense of self-employment in late career: Understanding the identity work of olderpreneurs', Work Employment and Society.

S. McNair (2006) 'How different is the older labour market? Attitudes to work and retirement among older people in Britain', Social Policy \& Society, 5(4), 485-494.

S. McNair (2010) A sense of a future: A study of training and work in later life (Leicester: The Nuffield Foundation / NIACE: 144).

M. B. Miles (1979) 'Qualitative data as an attractive nuisance: The problem of analysis', Administrative Science Quarterly, 24(4), 590-601.

H. R. Moody (2002). Aging: concepts and controversies (Thousand Oaks, CA: Sage).

M. H. Morris, D. F. Kuratko, M. Schindehutte and A. J. Spivack (2012) 'Framing the entrepreneurial experience', Entrepreneurship Theory and Practice, 36(1), 11-40.

G. Moss (2004). 'Provisions of trustworthiness in critical narrative research: Bridging intersubjectivity and fidelity', The Qualitative Report, 9(2), 359-374. Retrieved 26 April 2014 from http://www.nova.edu/ssss/QR/QR9-2/moss.pdf

J. O. Ogbor (2000) 'Mythicizing and reification in entrepreneurial discourse: Ideologycritique of entrepreneurial studies', Journal of Management Studies, 37(5), 605-635. 
[Type here]

C. Phillipson (1982) Capitalism and the construction of old age (London: The MacMillan Press).

D. E. Polkinghorne (2007) 'Validity issues in narrative research', Qualitative Inquiry, 13(4), 471-486.

PRIME (The Prince's Initiative for Mature Enterprise) (2011). Research. Retrieved 26 April, 2014 from http://prime.org.uk/tag/research/.

K. Riach (2007) '”Othering” older worker identity in recruitment', Human Relations, $60(11), 1701-1726$.

C. K. Riessman (2001) 'Analysis of personal narratives' in J.F. Gubrium and J.A. Holstein (eds), Handbook of interview research: Context \& method (Thousand Oaks, CA: Sage).

D. A. Shepherd (2003) 'Learning from business failure: Propositions of grief recovery for the self-employed' Academy of Management Review, 28(2), 318-328.

G. Singh and A. DeNoble (2003) 'Early retirees as the next generation of entrepreneurs', Entrepreneurship Theory and Practice, 27(3), 207-226.

M. R. Somers (1994) 'The narrative constitution of identity: A relational and network approach', Theory and Society, 23, 605-649.

D. Storey and R. Cressy (1996) ‘Small business risk: A firm-bank perspective’, CSME Working Paper 39 (April 1996). Coventry: Warwick Business School. ISSN: 0964-9328. 
[Type here]

The Economist (2010) Buttonwood: Old-age tension: Increasing the retirement age is inevitable and better than the alternatives. London: The Economist Group. Retrieved 26 April, 2014 from http://www.economist.com/node/17254452.

S. Vickerstaff and J. Cox (2005) 'Retirement and risk: the individualisation of retirement experiences?’ The Sociological Review, 53(1), 77-95.

P. Weber and M. Schaper (2004) 'Understanding the grey entrepreneur', Journal of Enterprising Culture, 12(2), 147-164.

T. Wainwright, E. Kibler, R. Blackburn and T. Kautonen (2012) 'Who are you calling old? Revisiting notions of age and ability amongst older entrepreneurs', Paper presented at ISBE 